\title{
Interrelation of prions with non-coding RNAs
}

\author{
R.N. Mustafin ${ }^{1} \otimes$, E.K. Khusnutdinova ${ }^{1,2}$ \\ ${ }^{1}$ Bashkir State University, Ufa, Russia \\ ${ }^{2}$ Institute of Biochemistry and Genetics, Ufa Research Center RAS, Ufa, Russia
}

Prions are alternative infectious conformations for some cellular proteins. For the protein $\mathrm{PrP}^{\mathrm{C}}$ ( $\mathrm{PrP}$ - prion protein, $\mathrm{C}$ - common), a prion conformation, called $\operatorname{PrPsc}^{\mathrm{Sc}}(\mathrm{S}-$ scrapie), is pathological. For example, in mammals the PrPSc prion causes transmissible spongiform encephalopathies accumulating in the brain tissues of $\mathrm{PrPSC}^{\mathrm{Sc}}$ aggregates that have amyloid properties. MicroRNAs and long non-coding RNAs can be translated into functional peptides. These peptides can have a regulatory effect on genes from which their non-coding RNAs are transcribed. It has been assumed that prions, like peptides, due to the presence of specific domains, can also activate certain non-coding RNAs. Some of the activated non-coding RNAs can catalyze the formation of new prions from normal protein, playing their role in the pathogenesis of prion diseases. Confirmation of this assumption is the presence of the association of alleles of microRNA with the development of the disease, which indicates the role of the specific sequences of noncoding RNAs in the catalysis of prion formation. In the brain tissues of patients with prion diseases, as well as in exosomes containing an abnormal PrPSc isoform, changes in the levels of microRNA have been observed. A possible cause is the interaction of the spatial domains of $\mathrm{PrP}^{\mathrm{sc}}$ with the sequences of the non-coding RNA genes, which causes a change in their expression. MicroRNAs, in turn, affect the synthesis of long non-coding RNAs. We hypothesize that long noncoding RNAs and possibly microRNAs can interact with $\operatorname{PrPc}^{\mathrm{C}}$ catalyzing its transformation into $\mathrm{PrPSC}^{\mathrm{Sc}}$. As a result, the number of $\mathrm{PrPSc}^{\mathrm{Sc}}$ increases exponentially. In the brain of animals and humans, transposon activity has been observed, which has a regulatory effect on the differentiation of neuronal stem cells. Transposons form the basis of domain structures of long non-coding RNAs. In addition, they are important sources of microRNA. Since prion diseases can arise as sporadic and hereditary cases, and hereditary predisposition is important for the development of pathology, we hypothesize the role of individual features of activation of transposons in the pathogenesis of prion diseases. The activation of transposons in the brain at certain stages of development, as well as under the influence of stress, is reflected in the peculiarities of expression of specific non-coding RNAs that are capable of catalyzing the transition of the PrPC protein to PrPSc. Research in this direction can be the basis for targeted anti-microRNA therapy of prion diseases.

Keywords: brain; long noncoding RNA; methylation; microRNA; prions; regulation; stem cells; transmissible spongiform encephalopathies.

\section{Взаимосвязь прионов с некодирующими РНК}

\author{
Р.Н. Мустафин ${ }^{1} \otimes$, Э.К. Хуснутдинова ${ }^{1,2}$ \\ ${ }^{1}$ Башкирский государственный университет, Уфа, Россия \\ ${ }^{2}$ Институт биохимии и генетики Уфимского научного центра \\ Российской академии наук, Уфа, Россия
}

Прионы - это альтернативные инфекционные конформации ряда клеточных белков. В отношении протеина $\operatorname{PrPC}^{2}(\operatorname{PrP}$ - от англ. prion protein, C - common, обычный) прионная конформация, получившая название $\mathrm{PrP}^{\mathrm{Sc}}$ (Sc - scrapie, скрейпи или почесуха овец), оказалась патологической. У млекопитающих $\mathrm{PrPSc}$ является этиологическим фактором трансмиссивных губчатых энцефалопатий, характеризующихся накоплением в головном мозге агрегатов $\mathrm{PrP}{ }^{\mathrm{Sc}}$, которые обладают амилоидными свойствами. МикроРНК и длинные некодирующие РНК могут транслироваться в функциональные пептиды, оказывающие регуляторное воздействие на гены, продуктами которых они служат. Сделано предположение о роли активации специфических некодирующих РНК под влиянием прионов в качестве одного из механизмов патогенеза прионных болезней. Обнаружены изменения уровней микроРНК в тканях головного мозга, а также в экзосомах, содержащих аномальную изоформу PrPSc у больных трансмиссивными губчатыми энцефалопатиями. Выявлены ассоциации аллелей микроРНК с развитием болезни, что говорит о возможной роли специфических последовательностей некодирующих РНК в катализе образования прионов из нормального белка. Предполагается, что измененные $\mathrm{N}$-концевые пространственные домены $\mathrm{PrPSc}^{\mathrm{C}}$ способны связываться с регуляторными последовательностями специфических генов некодирующих РНК. В результате активируется экспрессия данных некодирующих РНК, которые, в свою очередь, могут взаимодействовать c PrPC, катализируя их преобразование в $\mathrm{PrPSc}^{\mathrm{Sc}}$ Происходит экспоненциальный рост количества PrPsc. В головном мозге животных и человека наблюдается активность мобильных элементов, оказывающие регуляторное влияние на дифференцировку нейрональных стволовых клеток. Транспозоны составляют основу доменных структур длинных некодирующих РНК, служат важными источниками микроРНК. Так как прионные болезни могут возникать в виде спорадических и наследственных случаев, а на восприимчивость к заболеванию влияет полиморфизм в белок-кодирующих генах и генах микроРНК, можно предположить роль роль специфического состава и особенностей функционирования транспозонов в их патогенезе. Активация транспозонов в головном мозге на определенных 
стадиях развития, а также под действием стресса отражается в характере экспрессии специфических некодирующих РНК, способных катализировать переход белка $\mathrm{PrP}^{\mathrm{C}}$ в $\mathrm{PrP}^{\mathrm{Sc}}$. Исследование в данном направлении может стать основой для таргетной терапии прионных болезней с использованием микроРНК в качестве мишеней.

Ключевые слова: головной мозг; длинные некодирующие РНК; метилирование; микроРНК; прионы; регуляция; стволовые клетки; трансмиссивные губчатые энцефалопатии.

\section{HOW TO CITE THIS ARTICLE:}

Mustafin R.N., Khusnutdinova E.K. Interrelation of prions with non-coding RNAs. Vavilovskii Zhurnal Genetiki i Selektsii =Vavilov Journal of Genetics and Breeding. 2018;22(4):415-424. DOI 10.18699/VJ18.377

A term 'prion' was coined to mark proteinaceous infectious particles (hence prions) that are able to cause prion diseases a.k.a. transmissible spongiform encephalopathies (TSEs) in mammals. The PrPSc protein (PrP stands for prion protein $\mathrm{S}-$ for scrapie) is an example of such a prion with multiple $\beta$-layers that is a product of conformation transformation of the common $\mathrm{PrP}^{\mathrm{C}}$ protein $(\mathrm{C}-$ for common). However, $\mathrm{PrP}$ is not the only protein forming prions, as not all prions are pathogenic.

In the literature, the term has been used to mark selfpropagating alternative protein conformations, so this definition can be referred to many amyloid proteins as well. On the other hand, 'prion' also means that a protein's transmissibility has been proved (Harbi, Harrison, 2014).

The term 'amyloid' was first coined in 1838 by German botanist M. Shleiden to describe the starch (amylum is starch in Latin) component of plants. In 1854, P. Virkhov used this term to refer to the specific reaction of nerve-cell deposits to iodine falsely assuming that these substances are similar to starches. As it turned out later, the deposits were proteins, but they still have been known as amyloids (Kyle, 2001).

Amyloid fibrils are threadlike self-organizing peptide or protein aggregates that contain cross-link $\beta$-structures. Ribbon-like $\beta$-layers spread along the fibrils in which $\beta$-threads go perpendicular to fibril growth direction and are cross-linked by h-bonding. Typical amyloid fibrils have two or more $\beta$-layers laying one over the other. The presence of such structures has been proven with $\mathrm{x}$-ray and electron diffraction spectroscopy and solid-state NMR.

Amyloid fibrils are a structural state taken by polypeptides in relatively high concentrations in case they are not able to form more complex structures such as folds for a globular ferment structure or participate in a functional supramolecular complex (Tycko, 2014).

Formation of amyloids presents certain interest for medical studies, because the tissues contaminated by such amyloid diseases as T2D, neurodegenerative diseases (AD, PD and TSE), accumulate amyloid fibrils (Tycko, 2014). For instance, TSEs are characterized by the infectious properties of the amyloid proteins causing the disease, while the encephalopathies themselves are described as a group of neurodegenerative diseases affecting the nervous system of humans and animals (Saba et al., 2012). In humans TSE causes such conditions as Creutzfeldt - Jacob disease (CJD), GerstmannSträussler-Scheinker syndrome (GSS), and fatal familial insomnia (FFI); in sheep - scrapie and trembling disease; and in cattle - bovine spongiform encephalopathy. Effective diagnostics and treatment of TSEs are complicated by the absence of intravital diagnostic techniques to detect the pre-existing disease (Bellingham et al., 2012). TSEs may also have genetic etiology, occur sporadically without any known factors and gene mutations or can infect through food or contaminated medical tools (see Table) (Saba et al., 2012; Mabbott, 2017).

The cellular prion protein with common three - dimensional structure $\left(\mathrm{PrP}^{\mathrm{C}}\right)$ is a sialoglycoprotein with glycophosphatidylinositol anchor characterized by its high level of expression in a central nervous system (CNS), especially in neuron synapses (Rubenstein et al., 2018). Its molecular mass is $30-35 \mathrm{kDa}$ and it is encoded by the $P R N P$ gene. After its synthesis $\operatorname{PrP}^{\mathrm{C}}$ is first processed in the Golgi until its expression into a plasmatic membrane. The secondary structure of its C-end domain contains three $\alpha$-spirals and a short double-stranded $\beta$-folded layer (Mabbott, 2017). The glycine-rich N-end domain contains an octapeptide repeat composed of four tandem copies of highly conserved sequence PHGGGWGQ. It is assumed that the $\mathrm{N}$-end domain plays an important role in modulating the prion protein's physiological function as well as in the pathological reactions in case of prion diseases. Multiple studies have demonstrated that the Nend domain can interact with a wide spectrum of ligands such as $\beta$-layer rich conformers (in particular $\mathrm{PrPSc}$ in TSE, and the $\mathrm{A} \beta 42$ peptide in $\mathrm{AD})$; metal ions $\left(\mathrm{Cu}^{2+}\right.$ and $\mathrm{Zn}^{2+}$ ); lipids; glycosaminoglycans (give different, some- 
Prion diseases in humans and animals (Mabbott, 2017)

\begin{tabular}{|c|c|c|}
\hline Disease & Infected species & Path of infection \\
\hline Drug-induced CJD & Humans & Accidental medical contamination \\
\hline Sporadic CJD & Humans & $\begin{array}{l}\text { Somatic mutations or spontaneous conversions } \\
\text { of } \operatorname{PrPc} \text { into PrPsc }\end{array}$ \\
\hline Variant CJD & Humans & $\begin{array}{l}\text { Eating contaminated food or transfusion } \\
\text { of contaminated blood }\end{array}$ \\
\hline Familial CJD & Humans & Germline mutations of the $P R N P$ gene \\
\hline CSS & Humans & $\gg$ \\
\hline Trembling disease & Humans & Ritual cannibalism \\
\hline $\mathrm{FFI}$ & Humans & Germline mutations of the $P R N P$ gene \\
\hline Mad-cow disease & $\begin{array}{l}\text { Bovine } \\
\text { cattle }\end{array}$ & Eating contaminated food \\
\hline Scrapie & $\begin{array}{l}\text { Sheep, goats, } \\
\text { moufflons }\end{array}$ & $\begin{array}{l}\text { Eating contaminated food, horizontal } \\
\text { and vertical infection }\end{array}$ \\
\hline Chronic wasting disease & $\begin{array}{l}\text { Mooses, } \\
\text { deers }\end{array}$ & \\
\hline Mink TSE & Minks & Eating contaminated food \\
\hline Feline spongiform encephalopathy & Cats & $\gg$ \\
\hline $\begin{array}{l}\text { Spongiform encephalopathy } \\
\text { of exotic animals }\end{array}$ & $\begin{array}{l}\text { Antelopes, } \\
\text { Grater kudus }\end{array}$ & $\gg$ \\
\hline
\end{tabular}

times opposite activity properties to the protein including protection from oxidative stress and $\mathrm{PrP}^{\mathrm{Sc}}$ toxicity mediation); and nucleic acids (Eigenbrod et al., 2017). It also can be assumed that the changed conformation of $\mathrm{PrPSc}^{\mathrm{Sc}}$ results in $\mathrm{N}$-end domain disorder modulating its physiological function and enabling it to affect the genes of noncoding RNAs (ncRNA) by interaction with regulatory sequences or their gene regulators activating them in the way the peptides formed while ncRNA translation do. In rare cases, the activated ncRNAs can be a cofactor for the conformational transformation of $\mathrm{PrP}^{\mathrm{C}}$ into PrPSc, and if it happens, it causes a chain reaction with the exponential growth of $\mathrm{PrPSc}^{\mathrm{Sc}}$, which is typical for prion diseases. However, the probability of such activation is negligibly small due to the long incubation period typical for prion diseases.

In a CNS, the physiological development of $\mathrm{PrPC}^{\mathrm{C}}$ supports myelin homeostasis by interaction with $G$ protein-coupled receptor Gpr126 (a.k.a. Adgrg6) in the
Schwann cells. It has also been reported about many other $\operatorname{PrP}^{\mathrm{C}}$ functions in a CNS including a circadian rhythm, synaptic transmission, cognition, signal transduction, apoptosis regulation and protection from oxidative stress. Moreover, $\mathrm{PrP}^{\mathrm{C}}$ is expressed in many cellular populations of an immune system and secondary lymphoid organs. Although in mice $\mathrm{PrP}^{\mathrm{C}}$ depletion does not lead to apparent immunodeficiency, it can play its role in cellular activation, T-cell differentiation, intercellular interaction and phagocytosis (Mabbott, 2017). $\mathrm{PrP}^{\mathrm{C}}$ is a calpain substrate (calcium-sensing cysteine phosphatase that can be subjected to controlled activation) and may become neurotoxic in pathological processing and accumulate in cytosol (Rubenstein et al., 2018). It has also been found that the cellular prion protein of $\mathrm{PrP}^{\mathrm{C}}$ works as a receptor for the amyloid fibrils of $\alpha$-synuclein easing their internalization and endocytosis. Such reactions occur by direct interaction between $\alpha$-synuclein fibrils and the $\mathrm{N}$-end domain of $\mathrm{PrP}^{\mathrm{C}}$ In the cellular lines express- 
ing $\operatorname{Pr} P S c$, binding of $\operatorname{PrP}^{\mathrm{C}}$ and the fibrils prevents the formation and accumulation of $\mathrm{PrPSc}^{\mathrm{Sc}}$, as $\operatorname{PrP}^{\mathrm{C}}$ becomes inaccessible as the substrate for the pathological transformation (De Cecco, Legname, 2018).

In TSE one detects changes in the secondary, tertiary and quaternary structures of the PrP molecule that lead to increase in the number of $\beta$-folded layers. These changes have a strong effect on the physical, chemical and biological characteristics of PrP because the specific pathogenic isoform of $\mathrm{PrPsc}^{\mathrm{Sc}}$ is neurotoxic, relatively stable to protease cleavage and accumulates in infected tissues as insoluble aggregates. While particular mechanisms of these conformational and biological changes have been unknown, it has been demonstrated that they require additional chaperone molecules such as lipids, proteoglycans and RNAs (Mabbott, 2017). TSE progressing is related to the exponential growth of $\mathrm{PrP}^{\mathrm{C}}$ transformation into its abnormal isoform $\mathrm{PrP}^{\mathrm{Sc}}$ (Saba et al., 2012), which is characterized by the changed tertiary structure of the molecule, where the $\alpha$-spirals have transformed to make a new conformation with the $\beta$-layers (Simoneau et al., 2015). The characteristic histopathologic CNS changes in TSE include brain vacuolation, neurodegeneration, microgliosis, astrocytosis and pathological accumulation of PrPSc (Mabbott, 2017).

Similar to other neurodegenerative processes, TSE activates brain-resident immune cells, microglia cells and increases the number of astroglia cells. In many cases, these manifestations of TSE can be detected before the clinical symptoms of the disease or such signs of neurodegeneration as spongiosis and neuron death (Saba et al., 2012). Apart from $\mathrm{PrPSc}^{\mathrm{Sc}}$, there are other elements that can either affect TSE development or determine the clinical phenotype of the disease and susceptibility to a prion infection, e.g. it has been found that $\mathrm{PrP}^{\mathrm{C}}$-coding allelic $P R N P$ can participate in TSE pathogenesis. It has also been found that the polymorphism of the ZBTB38 gene $R A S A 2$ (RAS $\mathrm{p} 21$ protein activator 2 ) is associated with susceptibility to CJD in the UK, while in China an expressed association has been confirmed between SNP rs57095329 in miR-146a and susceptibility to FFI (Gao et al., 2018). Studying TSE microRNAs as infection diagnostic markers in animals consumed as food has been considered as a perspective direction of research, e.g. in recent studies they used quantitative PCR with inverse transcription to analyze the levels of candidate microRNAs in the blood plasma of scrapie-infected sheep. In this study, a significant association between the disease and the high levels of miR-342-3p и miR-21-5p has been indicated (Sanz Rubio et al., 2017).

\section{Role of microRNAs in prion disease pathogenesis}

TSE causes deregulation of certain microRNAs in prioninfected brain tissues(Bellingham et al., 2012). A set of experimental studies was designed and carried out to determine the role of microRNAs in prion disease pathogenesis. The studies detected deregulation of 15 microRNAs in the brain of prion-infected mice. The expression increased more than 2.5 times for miR-342-3p, miR-320, let-7b, miR-328, miR-128, miR-139-5p, miR-146a, and reduced more than 2.5 times for miR-338-3p and miR337-3p. In this set of microRNAs neurodegenerative deregulation had been determined only for miR-128, which is a confirmation of the conservative, prionspecific pattern of the microRNA differential expression associated with prion-induced neurodegeneration. For this dataset a lot of potential targets were predicted, including 119 genes whose regulation was disrupted in scrapie-infected mice (Saba et al., 2008).

The hyperexpression of miR-146a occurred simultaneously with prion deposits formation and microglia cells activation. In response to that, the transcription changed significantly including the proinflammatory transcription factors such as nuclear factor kappa-B (NF- $\mathrm{B})$ and signal pathways JAK-STAT. Microchip analysis made it possible to predict the role of miR-146a in regulation of the morphological changes in presence of activated microglia cells and phagocytosis mediators of oxidation bursts such as CYBA and NOS3.

Based on the results obtained miR-146a was indicated as a powerful modulator of a microglia cells that regulates their activation during prion-induced neurodegeneration (Saba et al., 2012). Increased expression of has-miR-342-3p and has-miR-494 was also detected in the brain of prion-infected macaques and human CJD models when compared to control groups. Increased expression of has-miR-342-3p was detected in the brain of sporadic CJD-infected humans. This microRNA is supposed to be used TSE diagnostic marker (Montag et al., 2009).

In TSE the early changes observed in brain tissues include reduction of the number of synapses and dendrite spikes followed by reduction of axon length and arborization. These pathological conditions are observed in the preclinical stages of the disease and are followed by changes in expression of the transcripts that include microRNAs. It was discovered that at the early stages of TSE expression of miR-16 increases in hippocampal neurons CA1. Modulation of miR-16 expression in mature hippocampal neurons by expression from a lentivirus imitated the reduction of axon length and arborization observed in vivo. An assumption was made that the increased expression of miR-16 causing changes in the regulation of the MAPK/ERK pathways took part in prion disease pathogenesis (Burak et al., 2018). The main molecular mechanisms resulting in a reduction of neural sinuses of the hippocampus and brain cortex in TSE have not yet been detected. However, it has turned out that many microRNAs, many of those enrich synapses, also regulate the local synthesis of protein in case 
of rapid response to prion stressors. The study analyzing the processing properties of the microRNAs isolated from synaptoneurosomes at the preclinical and clinical stages of TSE development demonstrated that at the preclinical stage miR-124a-3p, miR-136-5p, miR-376a$3 p$ were enriched. At the following stage, the levels of the microRNAs that were considered deregulated in the brain of TSE-infected mice increased, as well as those in AD models. These were miR-146a-5p, miR-142-3p, miR-143-3p, miR-145a-5p, miR-451a, miR-let-7b, miR-320, miR-150-5p. At the clinical stage of TSE a number of microRNAs decreased their level, including those in relation to the miR-200 family (miR-200a-3p, miR-200b-3p, miR-200c-3p, miR-141-3p, miR-429-3p) and cluster 182 (miR-182-5p, miR-183-5p) (Boese et al., 2016).

In cells $\mathrm{PrP}^{\mathrm{C}}$ and $\mathrm{PrP}^{\mathrm{Sc}}$ associate with exosomes, small $(50-130 \mathrm{~nm})$ vesicles released from the cells. The exosomes also contain microRNAs used for identification of microRNA signatures in TSE diagnostics. MicroRNA profiles were studied in the exosomes extracted from prion-infected nerve cells, and the study showed the increased levels of let-7b, let-7i, miR-128a, miR-21, miR-222, miR-29b, miR-343-3p, miR-424. It has confirmed there is a strong connection with microRNA in the neuron exosomes of prion-infected animals and this connection can be used both for TSE diagnostics and finding explanation for possible pathogenic mechanisms of the disease (Bellingham et al., 2012). Apart from studying the expression levels, analysis of the SNP genes participating in disregulation of hippocampal neurons CA1 in mice with early preclinical TSE stage. The study has shown an expressed association of SNP microRNAs blocking the binding sites of microRNAs and the 3'UTR genes coding GABA receptor subunits (Saba et al., 2014). The obtained results allow one to assume that in TSE development a special role is given to the ncRNA sequences, which has its effect on their spatial configuration and possible interaction with $\operatorname{PrP}^{\mathrm{C}}$ domains and their conformation transformation into $\mathrm{PrP}^{\mathrm{Sc}}$. A number of studies have also demonstrated that this transformation requires additional chaperon molecules such as RNAs (Mabbott, 2017). Changing the ncRNA sequences may also be important for a possible interaction with the $\mathrm{PrPSc}^{\mathrm{Sc}}$ isoforms that cause the effect similar to that one of peptides produced by translation of ncRNAs ( $\mathrm{Lv}$ et al., 2016). This interaction with the ncRNA genes may and their regulators may also involve the $\operatorname{PrP}^{\mathrm{C}} \mathrm{N}$-end domain. Disruption of its sequence (e.g. during conformation transformation into $\mathrm{PrPSc}^{\mathrm{Sc}}$ becomes important for modulation of the physiological functions of PrP. This assumption is based on a supposition that the $\operatorname{PrP}^{\mathrm{C}} \mathrm{N}$-end domain may interact with a wide spectrum of ligands including nucleic-acid sequences (Eigenbrod et al., 2017). However, conformation transformation of the globular
$\operatorname{PrP}^{\mathrm{C}}$ domain from $\alpha$-spirals into $\operatorname{PrP} \mathrm{Pc}^{\mathrm{Sc}} \beta$-layers may lead to significant modifications of the $\mathrm{N}$-end domain and affect its capability to interact with the regulatory gene sequences of specific ncRNAs, whose transcription products can serve as catalysts for the transformation of $\mathrm{PrP}^{\mathrm{C}}$ into $\mathrm{PrP}^{\mathrm{Sc}}$. The result is a chain reaction, since the $\mathrm{PrP}^{\mathrm{Sc}}$ $\mathrm{N}$-end domains, in their turn, activate ncRNA expression being a catalyst for their transformation.

\section{Regulation of noncoding RNAs by their own translation products}

Despite their name, ncRNAs can be translated, and the peptides formed this way have an ability to regulate protein-coding genes (Lv et al., 2016). More than 10\% of all the genomes of living organisms are composed of functional genes that contain small open reading frames (smORFs) encoding bioactive peptides (Saghatelian, Couso, 2015). Pre-microRNAs contain smORFs and are capable of both processing into mature microRNAs and of translation into mitochondrial intermediate peptidase (miPEP) that can enhance the transcription of the microRNAs they are binded with (Couzigou et al., 2015). In Arabidopsis thaliana each 50-th microRNA contains smORF to translate a pre-microRNA into a peptide. In Medicago truncatula miPEP171b is synthesized from pri-miR171b, while in Arabidopsis thaliana miPEP165a - from pri-miR165a (Lauressergues et al., 2015), so the biological activity of miPEP has been proven experimentally. Moreover, these peptides are successfully used to optimize the agronomical properties of agricultural plants, e.g. synthetic peptide miPEP172c that activates expression of miR172c stimulating radicle - knob formation in soy plants and increasing its crop yield through symbiotic interaction with nodule bacteria (Couzigou et al., 2016).

Though long noncoding RNAs (lncRNAs) do not contain conservative and long ORFs, they may also interact with ribosomes and translate into functional peptides (Ruiz et al., 2014), e.g. in animals lncRNAs translates into mioregulin, a peptide that controls the effectiveness of muscle contraction and relaxation. The peptide binds with the calcium ATPase of a smooth endoplasmic reticulum (SER) and has a regulatory effect on calcium engulfment (Anderson et al., 2015). In animals, the lncRNA produces the DWORF peptide that also works in SER (Nelson et al., 2016). In plants, the lncRNA produces different peptides such as IPS1 regulating phosphate engulfment; ENOD40 engaging in symbiosis with bacteria; COLDAIR and COOLAIR controlling flowering time (Zhang et al., 2013).

\section{Transposon and noncoding RNA activity in brain}

Noncoding RNAs play a vital role in controlling brain development and functioning of mature differentiated nerve cells. Neurogenesis in hippocampus is controlled by gene regulatory networks, transcription factors, 
IncRNA and microRNA, while lncRNA play a pivotal role in these processes (Deng et al., 2017). Experimental studies on mouse brain revealed the expression of 849 different lncRNAs, many of those overlapped with the protein-coding genes participating in the nerve function. At the same time these IncRNAs were not the so-called 'transcription noise' or the artifacts of chromatin remodeling (Mercer et al., 2008). Most of the lncRNAs had the expression pattern similar to the one of neurogenesis genes, which tells much about the role of lncRNA in regulation of corticogenesis by adjusting the expression of the determinants of neighboring genome regions in neurons (Aprea et al., 2013).

A strong interrelation has been observed between ncRNAs and transposable elements (TE or transposons) in regulation of stem cells differentiation including neurogenesis. Activation of certain TEs is necessary as for pluripotency support as for sequential stem-cell differentiation. In this case, depletion of certain specific lncRNAs may lead to TE disregulation and fetal development arrest, e.g. depletion of the LincGET lncRNA causes a total arrest of the late G2-phase of bicellular stage in mice. This effect is determined by LincGET inability to bind the ILF2, FUBP1 and hnRNP-U proteins and form a complex necessary for the cis-regulatory activity of LTR-containing retro-TE GLN, MERVL, ERVK (Wang et al., 2016). TEs can also be used as lncRNA genes, e.g. to support the identity of fetal stem cells retro-TE HERVH transcribes to become a nuclear lncRNA ( $\mathrm{Lu}$ et al., 2014). In evolution TEs are used to form the functional domains of lncRNA and become a part of $83 \%$ of them (Johnson, Guigo, 2014). TE activity in brain is observed not only in a fetal period but also in mature humans (Faulkner, 2011), animals and Drosophila (Richardson et al., 2014). This activity is assumed to be a source of neuron genetic heterogeneity in developing brain structures (Upton et al., 2015), as TEs have a regulatory function forming transcripts of functional ncRNAs (Gim et al., 2014).

Another role of TEs is to be an important source of microRNAs in animals (Borchert et al., 2011; Gim et al., 2014) and plants (Li et al., 2011; Lorenzetti et al., 2016), which is a confirmation of the universality and conservation of transposons evolution. At the same time, up to $40 \%$ of all the microRNAs that have a regulatory effect on the nerve-cell function are expressed in the brain. Many microRNAs affect neurotransmitter systems. Certain pre-microRNAs are even expressed at in neuron dendrites, where they are locally processed into the mature microRNAs regulating mRNA translation. These are miR-200c, miR-339, miR-332, miR-318, miR-29a, miR-7 и miR-137 enriched in synapses. Other microRNAs as miR-16, miR-221, miR-204, miR-15b are expressed at higher levels in presynaptic axons (Dwivedi, 2014). Another important source of micro-
RNAs is nonautonomous DNA TEs of medium reiteration frequency repeats (MER). On the 14-th day mouse fetuses demonstrate expressed activation of TE MER130 leading to neocortex formation. The nonautonomous TE MER130 that belong to the most important brain genes function as enhancers (Notwell et al., 2015). The close relation of TE and ncRNA can be a confirmation of TE activity in neural stem cells, since microRNAs and lncRNAs regulate gene expression while cellular differentiation. In neurogenesis somatic TE retrotransposition is a potential source of the genotypic neuron variations necessary for brain formation. The highest TE activity in this respect has been detected in the hippocampus, a center of neurogenesis, e.g. a sequence analysis of its cells gave in average 13.7 of the LINE-1 somatic insertions per a single neuron (Upton et al., 2015).

It has also been demonstrated that in TSE hippocampal neurons suffer microRNA deregulation (Burak et al., 2018), and this is a structure with the highest TE activity (Deng et al., 2017), which is assumed to be the basis of neural heterogeneity that plays the pivotal role in brain formation. This may lead to a conclusion that the peculiarities of the certain RNAs related to TEs through their brain regulation function can play their role in TSE development. Such a peculiarity can be accessibility of the certain genome sections containing TE sequences and microRNA genes that allow the PrPSc domains to interact with them. The result can be enhancement of the specific RNAs, a cascade of interacted processes developing in geometric progression that affects the expression of the certain lncRNAs, which, in their turn, may interact with the $\operatorname{PrP}^{\mathrm{C}}$ isoform catalyzing its transition into $\mathrm{PrPSc}$. It is not unlikely that microRNAs themselves can interact with prions as cofactors causing their conformation transformation. It is apparent that the probability of such events is extremely low, but if it occurs, the pathological process will be exponential, which is confirmed by both prion-disease epidemiology and their development pattern (long incubation period followed by fast development). Since every animal species has its own TE composition and positioning in the genome with its unique effect on the epigenetic properties of its functioning (Mustafin, Khusnutdinova, 2017), the described mechanism of TSE pathogenesis corresponds to the species-specific prion infection pattern.

\section{Role long noncoding RNAs in protein conformation catalysis}

The brain may be assumed to be the area where a prion disease develops due to the peculiarities of nerve-cell regulation reflected in expression of the specific microRNAs and lncRNAs affected by TEs. Long ncRNAs take an active part in expression control of the genes necessary for brain development. For example, lncRNA2393 facilitates the differentiation 
and proliferation of neural stem cells in the fascia dentata hippocampi (Deng et al., 2017), where high TE activity can be observed. Long ncRNAs interact with microRNAs hybridizing with partial complementary sequence and acting as molecular sponges that bind microRNAs and reduce their effect on target mRNAs (Fitzgerald, Caffrey, 2014). Long ncRNAs can catalyze different molecular processes on their own, serving as ribozymes or, which is more often, being a part of ribonucleoproteins (RNPs). Like proteins, lncRNAs have modular spatial organization and contain the discrete domains formed with TE participation (Johnson, Guigo, 2014).

To describe a possible mechanism of how a lncRNA can catalyze the conformation transformation of a common protein into a prion one should consider the similar mechanisms of prion-like domains (PLDs). PLDs enable for the 'functional reaction' of a protein that forms complexes of higher order and microscopic RNP granules. It is considered that protein and RNP concentration in confined space make gene regulation more effective. The biophysical properties of PLD-mediated interactions may explain the liquid-like properties of the RNP granules, as the PLDs expressed in vitro form hydrogels, so a PLD is the sequences with a low degree of complexity found the RNA-binding proteins associated with neurodegenerative amyotrophic lateral sclerosis (ALS). PLDs are rich in polar amino acids and glycines and in many ways are similar to the prion yeast protein that can be detected using the hidden Markov models (Hennig, 2015). In many-celled animals PLDs play a very important role in the subcellular cytoplasmic organization, especially in case of RNA homeostasis. In a study to investigate 20000 protein-coding human genes with Prion-Like Amino Acid Composition (PLAAC) 240 genes (1.2\%) turned out to contain the domains, whose structure was similar to the one of annotated prion yeast domains. From the 240 genes $72(30 \%)$ occurred to be RNAbinding ones, while 79 (33\%) - DNA-binding. Some of RNA-binding and PLD-containing proteins including ataxin 1, ataxin 2, TDP-43, FUS, TAF15, EWSR1, hnRNPA1, hnRNPA2, are important for the pathogenesis of a number of fatal neurodegenerative diseases such as ALS, frontoparietal dementia, and spinocerebellar ataxia (March et al., 2016). PLDs have also turned out to be important regulators of bacteriophage-prokaryote interaction and can be detected in all the bacteriophages of different bacterial groups and archaeons. These PLDs participate in phage attachment and penetration into a cell as well as in its reproduction (Tetz G., Tetz V., 2017), which is another confirmation of PLD natural universalism.

Low-complexity regions (LCRs) in their relation to proteins are sequences with low diversity of amino- acid residues if compared to high-complexity regions. LCRs can differ by their recapitulation degree (periodic or aperiodic motifs) and by their composition (homogeneous or heterogeneous). LCRs commonly include micro- and minisatellites, simple repeated sequences, homopolymers, genome heteropolymers, and amino-acid repeated sequences in proteins (Battistuzzi et al., 2016), e.g. glutamine/asparagines $(\mathrm{Q} / \mathrm{N})$-rich domains. For the first time, the relation between LCRs and prion proteins was demonstrated by M.D. Michelitsch и J.S. Weissman (2000), who found that Q/N-rich domains were highly likely to form self-propagating amyloid fibrils. They analyzed complete proteomic sequences of 31 species and a number of incomplete proteomic sequences to detect the $\mathrm{Q} / \mathrm{N}$-rich domains to find out that such domains occur in greater numbers in eukaryotic proteins that evolved as modular domains for the protein-protein interaction of 'polar-lightning' type. So, it has been demonstrated that the prion-like regulation in eukaryotic proteins can be a normal process of their multifunctional regulation (Michelitsch, Weissman, 2000). Here it should be reminded that prions are infectious proteins and it is their main property, while a prion-like domain has nothing to do with this infectious property, it just reflects the similarity of the amino-acid sequences and their propensity for aggregation, which allows one to consider PLD as a possible model of the effect ncRNAs have on prion conformation transformations, as TSE can occur as an infection, but in a number of cases it has genetic etiology (Saba et al., 2012; Mabbott, 2017). In addition, a study has confirmed the role PLDs play in the etiology of AA-amyloidosis in animals, which, as prion diseases, can be transmissive (Murakami et al., 2014).

PLDs are involved in liquid-phase transformation mediated gene regulation that leads to formation of RNP granules. Many PLDs in proteins are binded with paraspeckles, subnuclear bodies formed around lncRNAs. Protein RBM14 binds the key paraspeckle subcomplexes via their mediated PLDs. It takes PLD proteins RBM14 и FUS to form paraspeckles in a cell, where their endogenous copies have been knocked down. They form hydrogel with amyloid-like properties. PLDs launch the liquid-phase transformations, which underlines the importance of this body as a model for understanding of neurodegeneration (Hennig et al., 2015).

Commonly PLDs enable proteins to 'functionally aggregate' forming complexes of higher order and microscopic RNP granules. Proteins and RNAs concentrated in a confined space result in more effective processes of gene regulation, while the biophysical properties of PLD-mediated interactions may explain the liquid - phase properties of the granules since the PLDs expressed in vitro form loop-like networks that arrear as hydrogels. The hydrogels are functional amyloids, which has been confirmed by a study of RNA-binding 
protein FUS (Fused in Sarcoma) containing a PLD with multiple repeats $[\mathrm{G} / \mathrm{S}] \mathrm{Y}[\mathrm{G} / \mathrm{S}]$. The central tyrosine is necessary to form hydrogel and stress-granules in cytoplasm. As cytoplasmic RNP granules, nuclear bodies can also form complexes without membrane participation using protein-protein and RNA-protein interactions. Therefore, paraspeckles are nuclear bodies formed based on lncRNA NEAT1 (Nuclear Paraspeckle Assembly Transcript $1 / \mathrm{MEN} \varepsilon / \beta)$. Around 40 protein paraspeckles are known today and most of them are RNA-binding proteins enriched by RNA-recognizing motifs, a zinc finger and a K-homological domain. Paraspeckle occurrence is initiated by NEAT1 transcription followed by enrichment with the different proteins that coordinate paraspeckle accumulation. The genes encoding paraspeckle protein are FUS, TDP-43, SS18L1, HNRNPA1, TAF 15, EWSR1. Paraspeckles are sensitive to the stress caused by the structures induced by viral infections; by proteasomes and differentiation. They affect gene expression via keeping RNA in a nucleus through inverted repeats and sequestration of certain transcription factors (Hennig et al., 2015).

Experiments in vitro have also demonstrated there is a synergism between RNA effects and $\mathrm{PrPSc}^{\mathrm{Sc}}$ amplification. In this study, these were ultrasound-formed small RNA fragments that most easily converted into prions (Gonzalez-Montalban et al., 2011), which allows one to assume that microRNAs may serve as catalysts for $\mathrm{PrP}^{\mathrm{C}}$ transformation into $\mathrm{PrP}^{\mathrm{Sc}}$. Another study has also demonstrated that RNAs act as cofactors for formation of high-level de novo infectious prions facilitating PrP refolding into a pathogenic isoform (Timmes et al., 2013).

Research in vitro studied the role of RNAs as the strain-specific components of infectious prions. They demonstrated that depending on a kind of strains the effect of ribonuclease reduced the activity of $\mathrm{PrPSc}$ conversion via protein misfolding cyclic amplification (PMCA) while adding RNA restored the effectiveness of the PMCA conversion. These results have made it possible to assume that RNA molecules can serve as catalysts of prion replication, while the variability of particular prion strains can explain the strain-specific RNA dependencies (Saa et al., 2012).

Searching for the factor facilitating PrPSc infectivity was carried out in (Simoneau et al., 2015). The experiments showed that initially nonpathogenic recPrP similar to $\mathrm{PrP}^{\mathrm{C}}$ could initiate a prion disease in hamsters via its prion-like conformation (rich in $\beta$-layers) in presence of the RNAs purified of their scrapie-associated fibrils. Analysis of the infectious recPrP-RNA mixture detected two populations of small RNAs of 27 and 55 nucleotides in size, demonstrating a clear relation between the specific RNAs and the infectious properties of the prion amyloid (Simoneau et al., 2015).

Thus, there have been growing amount of proves of the role specific ncRNAs play in the pathogenesis of prion diseases. Since TEs is an important source of lncRNAs and micro RNAs, an assumption can be made that the individual composition and specific changes of transposons in ontogenesis may be the element triggering the development of TSE and other cerebral proteinopathies including AD, PD and HD all characterized by a structural transformation of specific host proteins into new $\beta$-layer-rich conformations.

\section{Conclusion}

It has been assumed that interaction of a prion tertiary structure with certain gene sequences of lncRNAs may be one of the mechanisms of prion disease pathogenesis. Such interaction can be similar to the self-regulation of ncRNA by the products of its own translation. It has been found that ncRNAs can be translated, while the peptides formed has a regulatory effect on ncRNA genes. Association of microRNA polymorphism with prion disease development as well as changes in the expression of certain ncRNAs in TSE allow one to assume that specific ncRNAs are able to catalyze $\operatorname{PrP}^{\mathrm{C}}$ transformation into a PrPSc isoform. Therefore, optimal interactions of $\mathrm{PrPSc}^{\mathrm{Sc}}$ with the genes of certain RNAs may cause the exponential growth of their amount, if the formed ncRNAs or the subproducts of their interaction are able to catalyze the transformation. MicroRNA activation by prion domains most likely potentiates the formation of microRNAs, whose regulation of the expression of certain genes may also stimulate the conformation transformation. It can also explain the species-specific character of prion infections as well as TSE long incubation period and fast progression. In TSE pathogenesis an important role is given to TEs to be the basis for the neural stem cell differentiation in the hippocampus triggered by TE ncRNAs.

\section{Conflict of interest}

The authors claim to have to conflict of interest to declare.

\section{References}

Anderson D.M., Anderson K.M., Cang C.L., Makarewich C.A., Nelson B.R., McAnally J.R., Kasaragod P., Shelton J.M., Liou J., Bassel-Duby R., Olson E.N. A micropeptide encoded by a putative long noncoding RNA regulates muscle performance. Cell. 2015;160: 595-606.

Aprea J., Prenninger S., Dori M., Ghosh T., Monasor L.S., Wessendorf E., Zocher S., Massalini S., Alexopoulou D., Lesche M., Dahl A., Groszer M., Hiller M., Calegari F. Transcriptome sequencing during mouse brain development identifies long noncoding RNAs functionally involved in neurogenic commitment. EMBO J. 2013;32(24):3145-3160.

Battistuzzi F.U., Schneider K.A., Spencer M.K., Fisher D., Chaudhry S., Escalante A.A. Profiles of low complexity regions in Apicomplexa. BMC Evol. Biol. 2016;16:47. DOI 10.1186/ s12862-016-0625-0. 
Bellingham S.A., Coleman B.M., Hill A.F. Small RNA deep sequencing reveals a distinct miRNA signature released in exosomes from prion-infected neuronal cells. Nucleic Acids Res. 2012;40(21):10937-10949.

Boese A.S., Saba R., Campbell K., Majer A., Medina S., Burton L., Booth T.F., Chong P., Westmacott G., Dutta S.M., Saba J.A., Booth S.A. MicroRNA abundance is altered in synaptoneurosomes during prion disease. Mol. Cell. Neurosci. 2016;71:13-24.

Borchert G.M., Holton N.W., Williams J.D., Hernan W.L., Bishop I.P., Dombosky J.A., Elste J.E., Gregoire N.S., Kim J.A., Koehler W.W., Lengerich J.C., Medema A.A., Nguyen M.A., Ower G.D., Rarick M.A., Strong B.N., Tardi N.J., Tasker N.M., Wozniak D.J., Gatto C., Larson E.D. Comprehensive analysis of microRNA genomic loci identifies pervasive repetitive-element origins. Mob. Genet. Elements. 2011;1(1):8-17.

Burak K., Lamoureux L., Boese A., Majer A., Saba R., Niu Y., Frost K., Booth S.A. MicroRNA-16 targets mRNA involved in neurite extension and branching in hippocampal neurons during presymptomatic prion disease. Neurobiol. Dis. 2018;112:1-13. DOI 10.1016/j.nbd.2017.12.011.

Couzigou J.M., Andre O., Cuillotin B., Alexandre M., Combier J.P. Use of microRNA-encoded peptide miPEP172c to stimulate nodulation in soybean. New Phytol. 2016;211(2):379-381.

Couzigou J.M., Lauressergues D., Becard G., Comier J.P. miRNAencoded peptides (miPEPs): A new tool to analyze the role of miRNAs in plant biology. RNA Biol. 2015;12:1178-1180.

De Cecco E., Legname G. The role of the prion protein in the internalization of $\alpha$-synuclein amyloids. Prion. 2018;12(1):23-27. DOI 10.1080/19336896.2017.1423186.

Deng B., Cheng X., Li H., Qin J., Tian M., Jin G. Microarray expression profiling in the denervated hippocampus identified long noncoding RNAs functionally involved in neurogenesis. BMC Mol. Biol. 2017;18(1):15. DOI 10.1186/s12867-017-0091-2.

Dwivedi Y. Emerging role of microRNAs in major depressive disorder: diagnosis and therapeutic implications. Dialogues Clin. Neurosci. 2014;16(1):43-61.

Eigenbrod S., Frick P., Bertsch U., Mitteregger-Kretzschmar G., Mielke J., Maringer M., Piening N., Hepp A., Daude N., Windl O., Levin J., Giese A., Sakthivelu V., Tatzelt J., Kretzschmar H., Westaway D. Substitutions of PrP N-terminal histidine residues modulate scrapie disease pathogenesis and incubation time in transgenic mice. PLoS ONE. 2017;12(12):e0188989.

Evans E.G., Pushie M.J., Markham K.A., Lee H.W., Millhauser G.L. Interaction between prion protein's cooperbound octarepeat domain and charged C-terminal pocket suggests a mechanism for N-terminal regulation. Structure. 2016;24(7):1057-1067.

Faulkner G.J. Retrotransposons: mobile and mutagenic from conception to death. FEBS Lett. 2011;585(11):1589-1594.

Fitzgerald K.A., Caffrey D.R. Long noncoding RNAs in innate and adaptive immunity. Curr. Opin. Immunol. 2014;26:140-146.

Gao C., Shi Q., Wei J., Zhou W., Xiao K., Wang J., Shi Q., Dong X.P. The associations of two SNPs in miRNA146a and one SNP in ZBTB38-RASA2 with the disease susceptibility and the clinical features of the Chinese patients of SCJD and FFI. Prion. 2018;12(1): 34-41. DOI 10.1080/19336896.2017.1405885.

Gim J., Ha H., Ahn K., Kim D.S., Kim H.S. Genome-wide identification and classification of microRNAs derived from repetitive elements. Genomics Inform. 2014;12(4):261-267.

Gonzalez-Montalban N., Makarava N., Savtchenko R., Baskakov I.V. Relationship between conformational stability and am- plification efficiency of prions. Biochemistry. 2011;50(37):79337940.

Harbi D., Harrison P.M. Classifying prion and prion-like phenomena. Prion. 2014;8(2):pii27960.

Hennig S., Kong G., Mannen T., Sadowska A., Kobelke S., Blythe A., Knott G.J., Iyer K.S., Ho D., Newcombe E.A., Hosoki K., Goshima N., Kawaguchi T., Hatters D., Trinkle-Mulcahy L., Hirose T., Bond C.S., Fox A.H. Prion-like domains in RNA binding proteins are essential for building subnuclear paraspeckles. J. Cell. Biol. 2015;210(4):529-539.

Johnson R., Guigo R. The RIDL hypothesis: transposable elements as functional domains of long noncoding RNAs. RNA. 2014;20(7): 959-976.

Kyle R.A. Amyloidosis: a convoluted story. Br. J. Haematol. 2001; 114(3):529-538.

Lauressergues D., Couzigou J.M., Clemente H.S., Martinez Y., Dunand C., Becard G., Combier J.P. Primary transcripts of microRNAs encode regulatory peptides. Nature. 2015;520(7545):90-93.

Li Y., Li C., Xia J., Jin Y. Domestication of transposable elements into MicroRNA genes in plants. PLoS ONE. 2011;6:e19212.

Lorenzetti A.P., A de Antonio G.Y., Paschoal A.R., Domingues D.S. Plant TE-MIR DB: a database for transposable element-related microRNAs in plant genomes. Funct. Integr. Genomics. 2016;16: 235-242.

Lu X., Sachs F., Ramsay L., Jacques P.E., Goke J., Bourque G., $\mathrm{Ng}$ H.H. The retrovirus HERVH is a long noncoding RNA required for human embryonic stem cell identity. Nat. Struct. Mol. Biol. 2014; 21(4):423-425.

Lv S., Pan L., Wang G. Commentary: primary transcripts of microRNAs encode regulatory peptides. Front. Plant Sci. 2016;7:1436.

Mabbott N.A. How do PrPSc prions spread between host species, and within hosts? Pathogens. 2017;6(4). pii: E60. DOI 10.3390/ pathogens6040060.

March Z.M., King O.D., Shorter J. Prion-like domains as epigenetic regulators, scaffolds for subcellular organization, and drives of neurodegenerative disease. Brain Res. 2016;1647:9-18.

Mercer T.R., Dinger M.E., Sunkin S.M., Mehler M.F., Mattick J.S. Specific expression of long noncoding RNAs in the mouse brain. Proc. Natl. Acad. Sci. USA. 2008;105(2):716-721.

Michelitsch M.D., Weissman J.S. A census of glutamine/asparagines-rich regions: implications for their conserved function and the prediction of novel prions. Proc. Natl. Acad. Sci. USA. 2000;97(22): 11910-11915.

Montag J., Hitt R., Opitz L., Schulz-Schaeffer W.J., Hunsmann G., Motzkus D. Upregulation of miRNA hsa-miR-342-3p in experimental and idiopathic prion disease. Mol. Neurodegener. 2009;4:36. DOI 10.1186/1750-1326-4-36.

Murakami T., Ishiguro N., Haguchi K. Transmission of systemic AA amyloidosis in animals. Vet. Pathol. 2014;51(2):363-371.

Mustafin R.N., Khusnutdinova E.K. Non-coding parts of genomes as the basis of epigenetic heredity. Vavilovskii Zhurnal Genetiki i Selektsii $=$ Vavilov Journal of Genetics and Breeding. 2017;21(6):742-749. DOI 10.18699/VJ17.30-o. (in Russian)

Nelson B.R., Makarewich C.A., Anderson D.M., Winders B.R., Troupes C.D., Wu F., Reese A.L., McAnally J.R., Chen X., Kevalali E.T., Cannon S.C., Houser S.R., Bassel-Duby R., Olson E.N. A peptide encoded by a transcript annotated as long noncoding RNA enhances SERCA activity in muscle. Science. 2016;351(6270):271-275.

Notwell J.H., Chung T., Heavner W., Bejerano G. A family of transposable elements co-opted into developmental enhancers in the mouse neocortex. Nat. Commun. 2015;6:6644. 
Richardson S.R., Morell S., Faulkner G.J. L1 retrotransposons and somatic mosaicism in the brain. Annu. Rev. Genet. 2014;48:127.

Rubenstein R., Wang K.K., Chiu A., Grinkina N., Sharma D.R., Agarwal S., Lin F., Yang Z. PrPC expression and calpain activity independently mediate the effects of closed head injury in mice. Behav. Brain Res. 2018;340:29-40.

Ruiz-Orera J., Messeguer X., Subirana J.A., Alba M.M. Long noncoding RNAs as a source of new peptides. Elife. 2014;3:e03523. DOI 10.7554/eLife.03523.

Saa P., Sferrazza G.F., Ottenberg G., Oelschlegel A.M., Dorsey K., Lasmezas C.I. Strain-specific role of RNAs in prion replication. J. Virol. 2012;86(19):10494-10504.

Saba R., Goodman C.D., Huzarewich R.L., Robertson C., Booth S.A. A miRNA signature of prion induced neurodegeneration. PLoS ONE. 2008;3:e3652.

Saba R., Gushue S., Huzarewich R.L., Manguiat K., Medina S., Robertson C., Booth S.A. MicroRNA 146a (miR-146a) is overexpressed during prion disease and modulates the innate immune response and the microglial activation state. PLoS ONE. 2012;7(2):e30832.

Saba R., Medina S.J., Booth S.A. A functional SNP catalog of overlapping miRNA-binding sites in genes implicated in prion disease and other neurodegenerative disorders. Hum. Mutat. 2014;35(10):1233-1248.

Saghatelian A., Couso J.P. Discovery and characterization of smORF encoded bioactive polypeptides. Nat. Chem. Biol. 2015;11(12):909-916.

Sanz Rubio D., Lopez-Perez O., de Andres Pablo A., Bolea R., Osta R., Badiola J.J., Zaragoza P., Martin-Burriel I., Toivonen
J.M. Increased circulating microRNAs miR-342-3p and miR-21$5 p$ in natural sheep prion disease. J. Gen. Virol. 2017;98(2):305310.

Simoneau S., Thomzig A., Ruchoux M.M., Vignier N., Daus M.L., Poleggi A., Lebon P., Freire S., Durand V., Graziano S., Galeno R., Cardone F., Comoy E., Pocchiari M., Beekes M., Deslys J.P., Fournier J.G. Synthetic scrapie infectivity: interaction between recombinant $\operatorname{PrP}$ and scrapie brain-derived RNA. Virulence. 2015;6(2):132-144. DOI 10.4161/21505594.2014.989795.

Tetz G., Tetz V. Prion-like domains in phagobiota. Front. Microbiol. 2017;8:2239.

Timmes A.G., Moore R.A., Fischer E.R., Priora S.A. Recombinant prion refolded with lipid and RNA has the biochemical hallmarks of a prion but lacks in vivo infectivity. PLoS ONE. 2013;8(7):e71081

Tycko R. Physical and structural basis for polymorphism in amyloid fibrils. Protein Sci. 2014;23(11):1528-1539.

Upton K.R., Gerhardt D.J., Jesuadian J.S., Richardson S.R., Sanchez-Luque F.J., Bodea G.O., Ewing A.D., Salvador-Palomegue C., van der Knaap M.S., Brennan P.M., Vanderver A., Faulkner G.J. Ubiquitous L1 mosaicism in hippocampal neurons. Cell. 2015;161(2): 228-239.

Wang J., Li X., Wang L., Li J., Zhao Y., Bou G., Li Y., Jiao G., Shen X., Wei R., Liu S., Xie B., Lei L., Li W., Zhou Q., Liu Z. A novel long intergenic noncoding RNA indispensable for the cleavage of mouse two-cell embryos. EMBO Rep. 2016;17:1452-1470.

Zhang J., Mujahid H., Hou Y., Nallamilli B.R., Peng Z. Plant long ncRNAs: a new frontier for gene regulatory control. Am. J. Plant Sci. 2013;4(5):1038-1045. DOI 10.4236/ajps.2013.45128. 